\title{
Decline of Diporeia in Lake Michigan: Was Disease Associated With Invasive Species the Primary Factor?
}

\author{
Courtney S. Cave ${ }^{1} \&$ Kevin B. Strychar ${ }^{1}$ \\ ${ }^{1}$ Annis Water Resources Institute, Grand Valley State University, Muskegon, Michigan, United States of America \\ Correspondence: Kevin B. Strychar, Annis Water Resources Institute, Grand Valley State University, Muskegon, \\ Michigan, 49441, USA. Tel: 1-616-331-8796. E-mail: strychark@gvsu.edu
}

Received: October 29, 2014

Accepted: November 11, 2014 Online Published: December 4, 2014

doi:10.5539/ijb.v7n1p93

URL: http://dx.doi.org/10.5539/ijb.v7n1p93

\begin{abstract}
Populations of the freshwater amphipod Diporeia spp. have steadily declined in Lake Michigan since the late 1980 's. Prior studies have provided inconclusive data on possible reasons for their decline. However, some authors suggest that food competition and/or diseases associated with aquatic invasive species (AIS), such as zebra mussels (Dreissena polymorpha), may have caused the collapse of Diporeia. In this project, the possibility of pathogens as the cause of the collapse of Diporeia has been examined. Linear regression modeling show a significant positive linear association between percent of Diporeia exhibiting a pathogenic infection and year $(\mathrm{r}=0.7202264, \mathrm{p} \leq 0.0124)$. Chi-square testing for independence was also used to test if there was an association between year and percent infection $\left(\mathrm{X}^{2}=50, \mathrm{df}=10, \mathrm{p} \leq 0.0001\right)$, implying significant association between year and infection. Hence, the introduction of zebra mussels and the diseases they carry may have been the root cause for the decline of Diporeia. Future research is needed to examine other invasive species for similar pathogens, including live studies showing direct causality between zebra mussels and the decline in Diporeia.
\end{abstract}

Keywords: Diporeia spp., Lake Michigan, aquatic invasive species, zebra mussels (Dreissena polymorpha), disease

\section{Introduction}

\subsection{Background}

Diporeia spp. are freshwater amphipods that used to be the most dominant crustaceans in the benthic layer of the Laurentian Great Lakes. High in lipid content, Diporeia have previously been considered the primary food source for many bottom feeders in the Great Lakes including whitefish (Coregonus clupeaformis), bloater (Coregonus hoyi), and slimy sculpin (Cottus cognatus) (Nalepa et al., 1998). Since the mid-1980's, however, populations of Diporeia began to disappear in Lake Michigan, declining over $95 \%$ in the last 15 years in some places (Figure 1). As a consequence, some fish populations also decreased, perhaps resulting from a shift to less nutritional food sources (Nalepa et al., 1998).

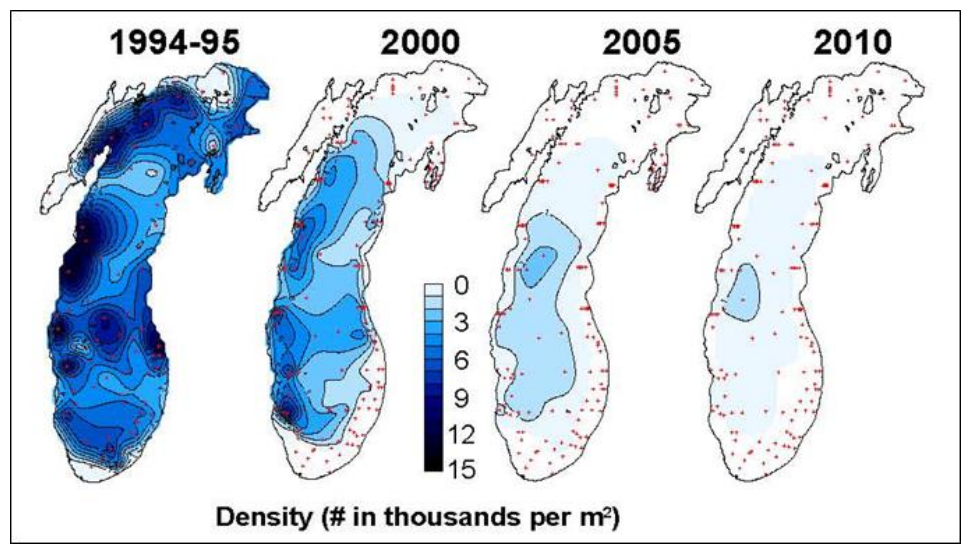

Figure 1. Densities of Lake Michigan Diporeia spp. continually decline from 1994 to 2010. Small red dots show NOAA (National Oceanic and Atmospheric Administration) sampling locations (from Nalepa et al., 2014) 
The disappearance of Diporeia has been postulated to be the result of the invasive Zebra (Dreissena polymorpha) and Quagga (Dreissena rostriformis) mussels introduced three years prior to the decline of Diporeia. Why Dresseina spp. had this effect on Diporeia is still not completely understood. One hypothesis is that the mussels led to decreased food availability due to food competition (Nalepa, 1989). However, there are some inconsistencies with this hypothesis. Diporeia and Dreissena coexist in Lake Superior, Lake Cayuga and isolated areas of Lake Michigan. Such observations suggest that the relationship between Diporeia and Dresseina is more complex than simply competition for food.

The second possibility is that mussels served as a vector for pathogenic organisms infecting Diporeia; this hypothesis is still being explored (Fanslow, pers. comm., 2013). In addition, anecdotal evidence indicates that during the early years of decline in Diporeia, crustaceans (i.e. shrimp) in many other locations of the United States were experiencing severe population declines, purportedly a consequence of disease. Rickettsia-like infection, i.e. Haplosporidia and Microsporidia, have all been observed in Diporeia tissues (Messick et al., 2004). The origin of these pathogens is not known. However, it is interesting to note that Rickettsia-like infections are found in Dreissena located in Greece (Molloy et al., 2001). Similarly, Haplosporidium pathogens were identified as the primary pathogen causing death in Crassostrea virginica (Eastern oyster) on the east coast of North America and in fresh water snails (Physella parkeri) in Douglas Lake (Michigan; Barrow, 1961). Microsporidia is also a common pathogen in freshwater shrimp (Gammarus fasciatus), an amphipod closely related to Diporeia. The associated pathologies suggest that any one of these diseases could infect and possibly be the cause of the decline in populations of Diporeia in the Great Lakes.

Taxonomically, Diporeia spp. belongs to the Phylum Arthropod, Subphylum Crustacea, Class Malacostraca, Order Amphipoda, and Family Pontoporeiidea. In years past, all Diporeia were classified as Pontoporeia hoyi (anonomous with $P$. affinis), however, taxonomists today believe there may be as many as eight species in the Great Lakes (Cavaletto et al., 1996).

\subsection{Objectives of the Study}

In order to better understand why Diporeia spp. crashed and are still unable to repopulate to their original concentrations, we designed our project to first (1) update the population density of Diporeia in Lake Superior's Batchawana Bay. This location has been identified in prior studies as a "safe haven" with high concentrations of healthy Diporeia that coexist with a high abundance of zebra mussels. Studies of abundance of Diporeia at this location have not been done since 2008. Secondly (2), we wanted to examine preserved ( $\sim 14$ years ago) samples of Diporeia tissue for pathogenic infection prior to the introduction of zebra mussels, and immediately there-after, from one general locality (i.e. Lake Michigan). In doing so we would be able to examine what pathogens existed in Diporeia's tissues before the presence of zebra mussels in Lake Michigan, and what pathogens exist in their tissues now that the mussels have become established.

\section{Materials and Methods}

\subsection{Field Work}

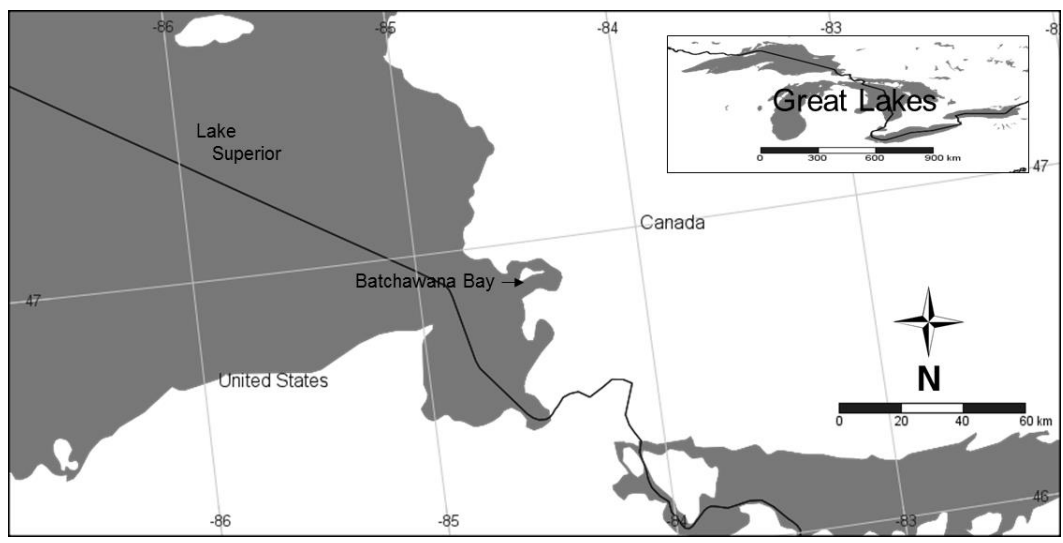

Figure 2. Map is showing sampling sites located in Batchawana Bay, Lake Superior, Canada

In collaboration with the National Oceanic and Atmospheric Association (NOAA) and Great Lakes Environmental Research lab (GLERL), Diporeia samples were collected from Lake Superior's Batchawana Bay in Ontario, 
Canada (Figure 2). GLERL provided a 7.3 meter research vessel that is equipped with a ponar grab which, when lowered, collects bottom sediment from the benthos. Using numerous site-specific locations known by GLERL after many years of collecting Diporeia, the anchored boat at each site allowed technical staff to lower the ponar to the bottom of the lake. Once bottom sediment was collected and retrieved, it was processed through a series of water flushes filtered through a ASTM round all-brass $500 \mu \mathrm{m}$ sieve until only a mixture of large material plus Diporeia remained. Collecting sediment using the ponar was repeated ten times at each location (ten locations) to ensure an accurate abundance of Diporeia was collected. After filtering the sediment, Diporeia was manually removed with tweezers from the remaining material. The collected Diporeia samples were further subdivided into two aliquots. The first aliquot was placed in liquid nitrogen and later transferred to a $-80^{\circ} \mathrm{C}$ freezer for future analyses. The second aliquot was placed into a $-20^{\circ} \mathrm{C}$ freezer and retrieved as needed for this project.

\subsection{Labwork: Histology}

Diporiea collected from this study in addition to samples provided by NOAA, were prepared for histological studies. Samples of Diporeia provided by NOAA were originally collected from Lake Michigan since the late 1980's.

All tissues regardless of their date or site of collection were prepared and analyzed using similar methodologies. All samples were first stained in Rose Bengal dye (Sigma-Aldrich, USA) and then placed in 10\% formalin (Sigma-Aldrich, USA) which maintains and preserves the tissue. Samples are then processed for microscopy. The purpose of processing tissue samples is to remove water from the tissue and replace it with a solid medium that will allow for thin sectioning. Individual Diporeia are removed from the formalin solution and placed into a histology cassette. Each cassette held ten Diporeia $(\mathrm{n}=10)$. The Diporeia in these cassettes are then processed using a series of increasing graded ethanol (Sigma-Aldrich, USA) solutions to dehydrate the tissue. Once complete, tissue was then placed in xylene (Sigma-Alrich, USA), which is a clearing agent that removes the alcohol from the previous step. Each cassette was placed, in order, in an $80 \%, 90 \%, 95 \%$, and two changes of $100 \%$ ethanol solutions, followed by two washes of $100 \%$ xylene. Each cassette was then incubated for 20 minutes in each respective solution (Bergman, per comm., 2013). Following incubation in graded ethonal, the cassettes were placed in tissue trays sprayed with HistoPrep Mold Releasing Agent (Fisher Scientific, USA). Each sample of Diporeia was then placed into a metal embedding tray using tweezers and submerged in liquid paraffin (wax) baths $\sim 30$ minutes. Immersion in liquid paraffin for 30 minutes allowed the tissue to become completely infiltrated with wax. Prior spraying of the trays was important as it helped with the removal of the solid wax block after cooling. Blocks not prepared in this manner chipped and fell apart and were too difficult to remove. Once infiltration was complete, each wax block containing a single Diporeia sample were left to cool for at least 3 hours at room temperature. Due to the small size of Diporeia, the wax outside a $1 \mathrm{~cm}$ radius of the organism was heated to $55^{\circ} \mathrm{C}$ and removed using a vacuum infiltrator and paraffin dispenser (Lipshaw Inc.). Preparring the Diporeia sample in this manner assisted in the latter processes of sagitally sectioning the wax block with a sliding microtome (Bausch \& Lomb, Rochester, USA).

In order to collect thin-sections of Diporeia tissues, each wax block needed to be secured in the sliding microtome. Each collected thin-section $(5-8 \mu \mathrm{m})$ was transferred to a warm water bath at $36^{\circ} \mathrm{C}$ to ensure the wax section was free of "wrinkles". The sections were then placed on poly-prep-lysine coated glass slides (Sigma-Aldrich, USA) followed by placement of the slides on a slide warmer (Sigma-Aldrich, USA) at $46^{\circ} \mathrm{C}$ for 24 hours. This procedure ensured that the thin sections adhered to the slides. After heating the prepared sections for 24 hours, the slides were exposed to a graded series of ethanol and xylene solutions in reverse order as described earlier. The graded series of ethanol and xylene solutions helped to remove the wax from each slide, leaving only the Diporeia tissue. Each slide was then incubated in a solution consisting of $65 \%$ ethanol and $5 \%$ hydrochloric acid for 5 minutes. The purpose of the aforementioned step was to remove any Rose Bengal dye that the tissue may have.

Mayer's Hematoxylin and Eosin Y stains (Sigma-Aldrich, USA) were then used to stain tissues adhering to the glass slides, followed by light and fluorescent microscopy to identify and characterize infected Diporeia tissue. The protocol used was a modified version from Lillie (1965), and is as follows:

- Immerse tissue with Mayer's Hematoxylin;

- Incubate for 10 minutes;

- Rinse and run room temperature tap water over sections for 10 minutes;

- Immerse with working Eosin Y Stain;

- Allow to incubate for 30 seconds;

- Rinse with tap water until water runs clear off of a slide;

- Clear, and mount tissue 


\subsection{Statistical analysis}

The statistical analyses and figures in this study only pertain to Lake Michigan Diporeia samples. We did not statistically compare pathogens of Diporeia tissues collected from Lake Superior as there were too few archived samples to generate any historical trends. Statistically comparing these two localities, one with plenty of replicates collected over time and one with too few (or none), introduces significant error.

However, all Lake Michigan samples were tested using linear regression and chi-square analyses. Linear regression was used, using year as the predictor and percent of pathogens present. A chi-square test for independence was also used to determine if there is association between year and presence of pathogens. All analyses were completed using the R-Statistic (R Core Team, 2013). The pathogen data for Diporeia tissue prior to 2005 was collected by Messick et al. (2004).

\section{Results}

\subsection{Field work}

The purpose of collecting Diporeia from Batchwana Bay (Lake Superior) was to update the status of the population density of Diporeia since presence/absence monitoring began in 1977, and to provide researchers with Diporeia tissue for future research projects. Based on the average number of Diporeia collected in the ponar sample, the observed population was 585 Diporeia $\mathrm{m}^{-2}$.

\subsection{Lab work: histology}

The pathology of Diporeia was assessed using both light and fluorescent microscopy in all tissue samples. Tissue was determined to be infected if it had a basophilic body (Figure 3A) and/or a budding structure (Figure 3B). Basophilic bodies (or mass) are structures within the tissue that are abnormal and are darker in color because they absorb more dye (Figure 3A). These masses are involved in the innate immune system of an amphipod's response to pathogens (Martinez, 2007). Basophilic bodies are often found in the legs and along the spine of Diporeia. The second prevalent structure found in Diporeia tissues were budding structures (Figure 3B). These structures had projections off of the cellular body suggesting possible fungal infection.
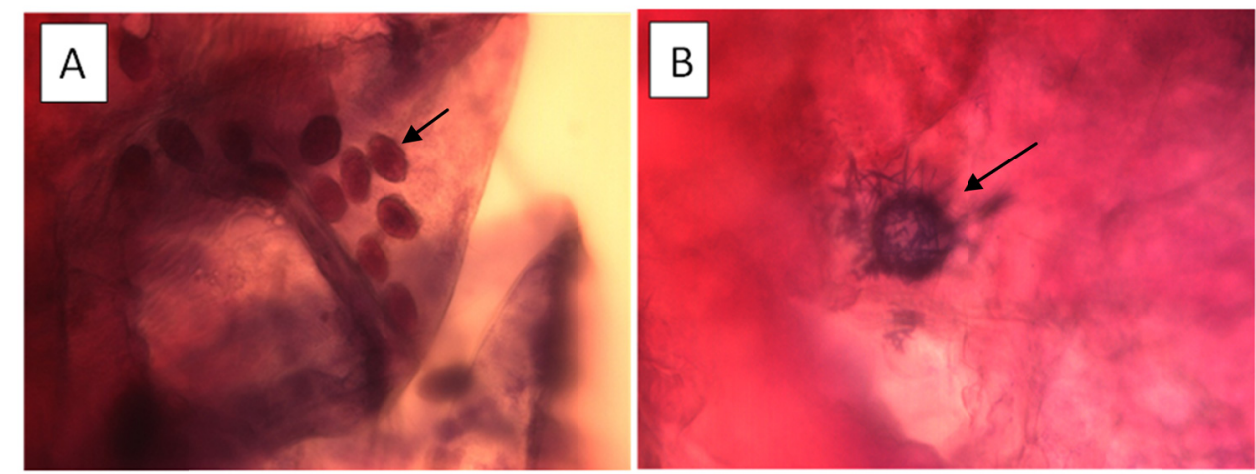

Figure 3. Analysis using fluorescent microscopy. (A) Basophilic bodies (black arrow) observed at 400x. Bodies are observed in proximity to one another. (B) Budding structure (black arrow) observed at 400x. These structures were typically observed scattered throughout the body tissues of Diporeia spp.

Examination of Lake Michigan Diporeia has been done previously on samples that were collected in 2000 and earlier (Messick, 2004). Examination of these historically relevant samples was to provide more recent insight into the current state of Diporeia tissue and disease. For Diporeia collected in 2005 , it was found that $\sim 18.9 \%$ exhibited infection versus 2010 samples, which showed $\sim 29.2 \%$ pathogenic infection.

Diporeia that had pathogenic infections are further categorized into those that had (1) basophilic masses or bodies, versus those that had (2) budding structures. In 2005, $63.6 \%$ of Diporeia exhibited basophilic bodies or masses, with the remaining being associated with budding structures. In 2010, 71.4\% exhibited basophilic bodies or masses. A linear regression model was used as a predictor to determine if year of infection played a role in the density decline of Diporeia populations (Figure 4). The linear regression was significantly positive $(\mathrm{r}=0.7202264, \mathrm{p} \leq 0.0124)$. A Chi-square test for independence, (Figure 5), was also used to test if there was an association between year and percent pathogens observed in Diporeia tissues. Values obtained were $\mathrm{X}^{2}=50, \mathrm{df}=$ $10, p \leq 0.0001$, implying significant association between year and pathogen incidence. 


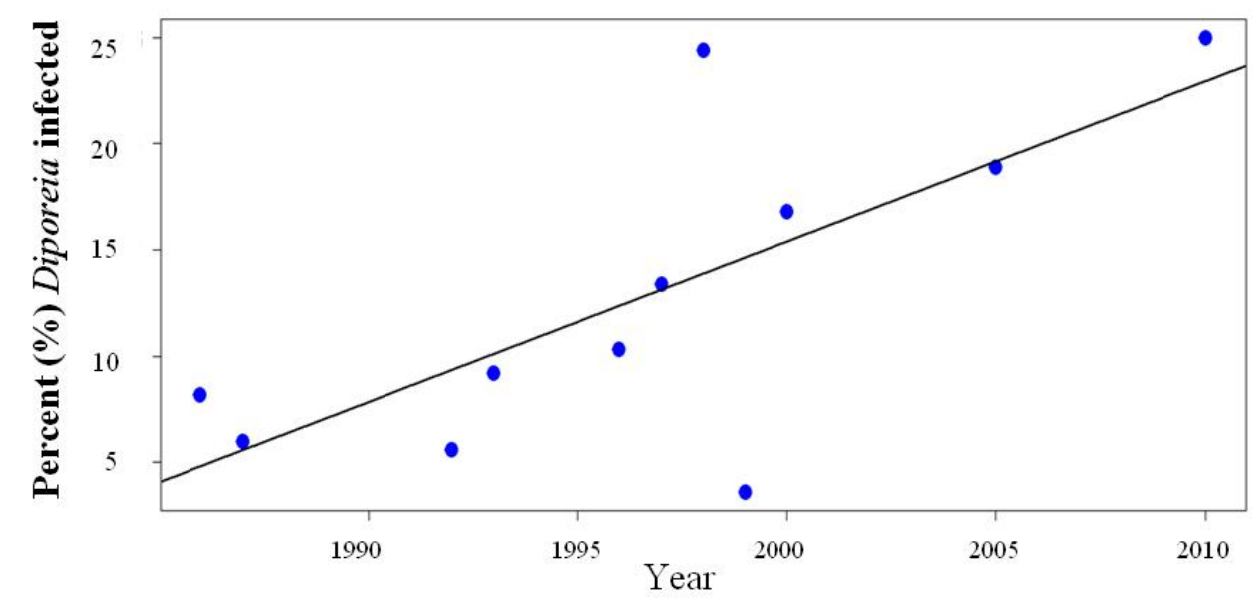

Figure 4. Linear regression analysis using R-statistics. Year was used as a predictor for percent pathogens found in Diporeia tissue collected from Lake Michigan (analyses resulted in $r=0.7202264, p \leq 0.0124$ )

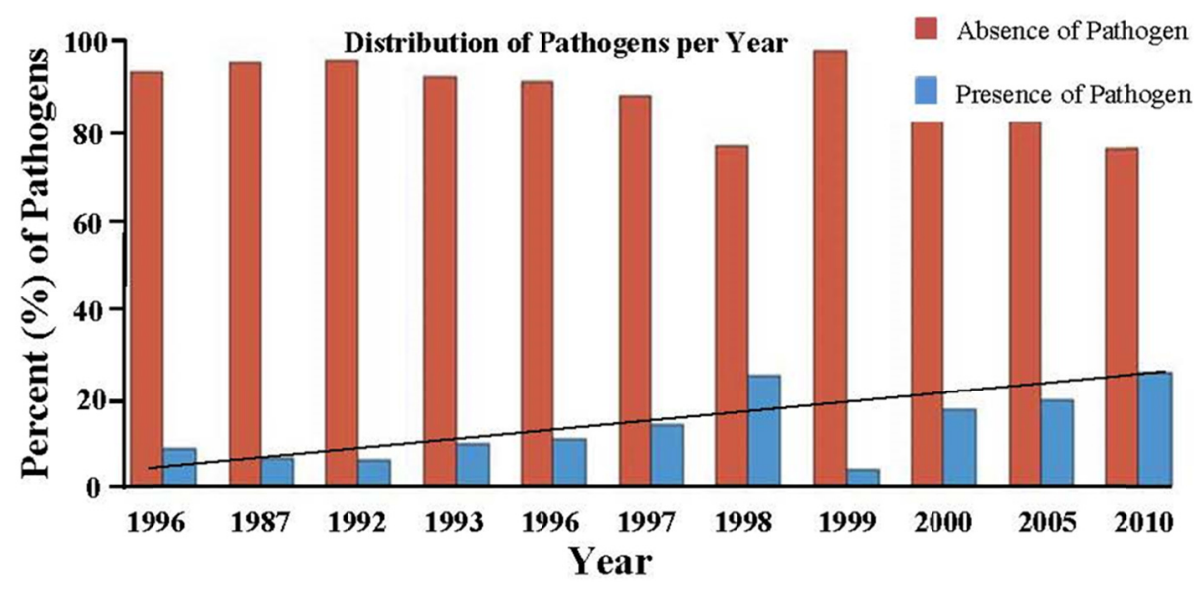

Figure 5. Chi-square analysis for independence using R-statistics for percent pathogens found in Diporeia tissue, collected from Lake Michigan (analyses resulted in $\mathrm{X}^{2}=50, \mathrm{df}=10, \mathrm{p} \leq 0.0001$ )

\section{Discussion}

The Diporeia population in Batchawana Bay, Lake Superior (Canada), does not appear to be affected by the introduction of zebra mussels. In our abundance analyses, we observed an increase in the number of Diporeia per square meter. The increase in density of Diporeia follows an important trend where the natural population for that locality of Diporeia initially fell in 1977 from 675 Diporeia $\mathrm{m}^{-2}$ to 481 Diporeia $\mathrm{m}^{-2}$ in 1978; why the population crashed is not known. However, in 2001 the population increased to 529 Diporeia $\mathrm{m}^{-2}, 570$ Diporeia $\mathrm{m}^{-2}$ in 2008, and as we observed, 585 Diporeia $\mathrm{m}^{-2}$ in 2013 . This is particularly important as the density data shows the population of Diporeia not only stabilizing, but it continues to exhibit growth. Since zebra mussels are also abundant in this region, we can only speculate that this particular Diporeia population may have developed resistance to diseases it shares with the mussels. Alternatively, it is possible that the Diporeia living in Lake Superior have evolved/mutated from breeding with other healthier populations and are now, perhaps, a genetic sub-type of the original population. It is also plausible that the population in Lake Superior have developed some type of tolerance to the specific diseases that are causing population crashes elsewhere. Another possibility to consider is food availability as it is also possible that more food exists in Lake Superior compared to other Great Lakes, for instance, Lake Michigan. Nalepa et al. (2006) suggested that the decline of Diporeia in Lake Michigan was possibly due to food competition, resulting from the introduction of zebra mussels. We speculate whether more food is available in Lake Superior and as a consequence, there is less competition between Diporeia and zebra mussels. 
Microscopy analyses of Lake Michigan Diporeia samples from 2005 and 2010 compared with prior tissue analyses show an overall increase in the prevalence of pathogens found in Diporeia since 1986. This is apparent in both the linear regression model (Figure 4) and the chi-square analysis (Figure 5). The overall increasing trend is consistent with the hypothesis that the invasion of zebra mussels in the Great Lakes has caused Diporeia's population crash (Nalepa et al., 2006). Zebra and quagga mussels invaded the Great lakes in the late 1980's (Nalepa et al., 1998); Diporeia populations have crashed in most areas since that time. Our data also shows an overall increase in pathogens found in Diporeia tissue since the introduction of the zebra mussel. Although it is possible that the increase in tissue pathogens observed in Diporeia might be caused by stress associated with increased feeding pressures, it seems more likely that the diseases (not present before the arrival of zebra mussels) are a direct consequence of a foreign invader(s), such as zebra mussels. Hence, an increase in infected Diporeia tissue might suggest that competition for food may have been a secondary effect caused by the primary effect, namely disease. The correlation between population decline in Diporeia, increased pathogenic infection and disease, and purported increased population of zebra mussels (Nalepa et al. 2006) supports this hypothesis.

Although most areas in the Great Lakes have experienced a decline in Diporeia populations since the introduction of zebra mussels, there are some locations that have not been affected by declining populations. Isolated areas of Lake Michigan and Lake Huron still support minimal Diporeia populations (Nalepa et al., 1998). Lake Superior's population of Diporeia has remained largely unchanged as supported by our sampling of Batchawana Bay. Diporeia's stability in Lake Superior may be attributed to multiple factors as discussed above. One more recent anecdote for their survival is that the greater depths of Lake Superior may have provided a 'safe-haven' compared to other shallower areas that Diporeia typically inhabited.

Lastly, it is also possible that the budding structure found in the tissue's of Diporeia may not be pathogenic and/or may be present as a commensal (Messick et al., 2004). As a consequence, more studies are needed to confirm any speculation. Because the identity of these budding structures is unknown, it should not be assumed that they are necessarily harmful to Diporeia. Future research needs to identify what these budding structures are and whether they are "infecting" Diporeia tissue and having a negative consequence.

\section{Conclusions}

Analyses in this study have shown a significant increase in pathogenic infection and immune-type response since the invasion of the zebra mussels in 1986. The positive correlations suggest that zebra mussels may have acted as a vector for pathogen(s) that infected Diporeia. Some inconsistencies exist with this hypothesis, however. For instance, healthy Diporeia populations have remained steady since the invasion of zebra mussels in certain areas in Canada. Future research should involve identifying these pathogens (e.g. genomics) and how the infections are affecting Diporeia physiology. In addition, both zebra and quagga mussel tissues should be analyzed for similar pathogens that are identified in Diporeia tissue.

\section{Acknowledgments}

This work could not have been done without support from the R.B. Annis Water Resources Institute Foundation and the D.J Angus-Scientech Undergraduate Student Internships for summers 2013 and 2014 provided by The Annis Water Resources Institute, Grand Valley State University. Additional support was provided by NOAA through David Fanslow whose technical help, in-depth knowledge, and patience made this work possible. We also thank Patrick McEnaney who helped collect samples and Gavin Christie (Division Manager) at the Great Lakes Laboratory for Fisheries and Aquatic Sciences for organizing permits allowing us to collect samples in Canada. We appreciate help from Dr. Sango Otieno at Grand Valley State University, statistical consulting center, who reviewed and analyzed this data, without whom this work would not have seen completion.

\section{References}

Barrow, J. H. J. (1961). Observations of a haplosporidian, Haplosporidium pickfordi sp. nov. in fresh water snails. Trans Am Microsc Soc, 80, 319-32. http://dx.doi.org/10.2307/3223643

Bergman, D. (2013). Personal communication.

Cavaletto, J., Nalepa, T., Dermott, R., Quiggley, W., \& Lang, G. (1996). Seasonal variation of lipid composition, weight, and length in juvenile Diporeia spp. (Amphipoda) from lakes Michigan and Ontario. Can J Fish Aquat Sci, 53, 2044-2051. http://dx.doi.org/10.1139/cjfas-53-9-2044

Fanslow, D. (2013). Personal communication.

Lillie, R.D. (1965). Histopathologic technique and practical histochemistry. New York: McGraw-Hill. 
Martinez, F. (2007). The Immune System of Shrimp. Boletines Nicovita, July-September, 2007. Retrieved from http://www.nicovita.com.pe/cdn/Content/CMS/Archivos/Documentos/DOC_257_2.pdf

Messick, G. A., Overstreet, R. M., Nalepa, T. F., \& Tyler, S. (2004). Prevalence of parasites in amphipods Diporeia spp. from Lakes Michigan and Huron, USA. Dis Aquat Org, 59, 159-170. http://dx.doi.org/10. 3354/dao059159

Molloy, D. P, Giamberini, L., Morado, J. F., Fokin, S. I., \& Laruelle, F. (2001). Characterization of intracytoplasmic prokaryote infections in Dreissena sp. (Bivalvia: Dreissenidae). Dis Aquat Org, 44, 203-216. http://dx.doi.org/10.3354/dao044203

Nalepa, T. F., Fanslow, D. L., Foley, A. J. III., Lang, G. A., Eadie, B. J., \& Quigley, M. A. (2006). Continued disappearance of the benthic amphipod Diporeia spp. in Lake Michigan: is there evidence for food limitation? Can J Fish Aqua Sci, 63, 872-890. http://dx.doi.org/10.1139/F05-262

Nalepa, T. F., Hartson, D. J., Fanslow, D. L., Lang, G. A., \& Lozano, S. J. (1998). Declines in benthic macroinvertebrate populations in southern Lake Michigan, 1980-1993. Can J Fish Aqua Sci, 55, 2402-2413. http://dx.doi.org/10.1139/f98-112

Nalepa, T.F. (1989). Estimates of macroinvertebrate biomass in Lake Michigan. Can J Fish Aquat Sci, 44, 515-524. http://dx.doi.org/10.1016/S0380-1330(89)71499-4

Nalepa, T.F., Fanslow, D. L., Lang, G.A., Mabrey, K., \& Rowe, M. (2014). Lake-wide benthic surveys in Lake Michigan in 1994-1995, 2000, 2005, and 2010: Abundances of the amphipod Diporeia spp. and abundances and biomass of the mussels Dreissena polymorpha and Dreissena rostriformis bugensis. NOAA Technical Memorandum GLERL-164. NOAA, Great Lakes Environmental Research Laboratory, Ann Arbor, MI, 21 pp. Retrieved from http://www.glerl.noaa.gov/ftp/publications/tech_reports/glerl-164/tm-164.pdf

R Core Team. (2013). R: A language and environment for statistical computing. R Foundation for Statistical Computing, Vienna, Austria. Retrieved from http://www.R-project.org

\section{Copyrights}

Copyright for this article is retained by the author(s), with first publication rights granted to the journal.

This is an open-access article distributed under the terms and conditions of the Creative Commons Attribution license (http://creativecommons.org/licenses/by/3.0/). 